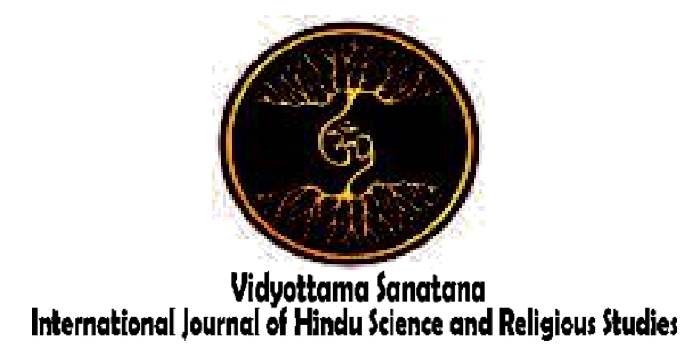

Vol. 2 No. 1 May 2018

\title{
Hinduism Humanity at Ratu Bagus Ashram In The Muncan Village, Selat District, Karangasem Regency
}

\author{
By: \\ I Ketut Wisarja \\ Institut Hindu Dharma Negeri Denpasar \\ E-mail: ketutwisarja@ihdn.ac.id
}

Received: September 05, 2017

Accepted: April 17, 2018

Published: May 31, 2018

\begin{abstract}
The relationship among the religions in Indonesia is very sensitive; it must be a serious effort to transform this relationship into something that dynamic. The implementation of the humanist religion in a practical is very important discourse in Indonesia. There are many religious groups in Indonesia, and each group has its own characteristics and a vital role to maintain a harmonious of society in Indonesia. One of the religious group of Ratu Bagus Ashram in Muncan village, Karangasem Bali, which is trying to dedicate the practice of religion and human services simultaneously. The research questions are: (1) Why was Ratu Bagus Ashram founded in the Muncan village, Selat district, Karangasem regency?; (2) How is the implementation of Hinduism humanity at Ratu Bagus Ashram community in the Muncan village, Selat district, Karangasem regency?; (3) What are the implications of Hinduism humanity at Ratu Bagus Ashram community in the Muncan village, Selat district, Karangasem regency?

This research is intended to: (1) To describe the reason of the foundation of Ratu Bagus Ashram in the Muncan village, Selat district, Karangasem regency; (2) To reveal the humanity implementation of Hinduism in community of Ratu Bagus Ashram in the Muncan village, Selat district, Karangasem regency; (3) To understand the implications of Hinduism humanity at Ratu Bagus Ashram community in the Muncan village, Selat district, Karangasem regency. Some methods that used in this research to obtain a valid data are as follows: (1) observation; (2) interviews; (3) literature study; and (4) document study. The three main issues analyzed
\end{abstract}


using several theories, namely: Social Exchange Theory, Critical Theory, and Hermeneutics Theory.

The results of this research are: (1) The reason of the foundation of Ratu Bagus Ashram in the Muncan village, Selat district, Karangasem regency are: First, to creates physical and spiritual health for the wider community; Second: to develops a religious society; Third: to introduces the importance of the spiritual as the most important of everything; (2) The humanity implementation of Hinduism in the community of Ratu Bagus Ashram are: First, to create a sense of peace and happy in ourselves, community, and the universe; Second, to reduces poverty and economic improvement of ashram community by giving scholarships for the student in school and university, giving a complimentary houses and foods, carry out a mass cremation, and establish banks; Third, giving a health service like intense tutuh, shaking, and laugher; (3) The implications of Hinduism humanity at Ratu Bagus Ashram are: First, the self-development of the students, by increasing people's spirituality, improve community health, improve community financial, increasing social awareness, and improve the intellectual, emotional, and spiritual intellectual of the community; Second, improving social relationship, through participated in social activities in societies around the Ashram, and also the societies participated in any activity at the Ashram, there is benefit of sharing between the Ashram communities and surrounding societies; Third, international networks, such as a lot of foreigners who doing the bio-energy meditation exercise or shaking in the Ashram, and they also respect Hindu tradition; Fourth, because of many people, both from domestic and abroad want to follow the practice of shaking, therefore the Ashram community must do everything that it can develop the Ashram.

Key words: Hindu, Humanity, The principle of humanity in the community of Ratu Bagus Ashram.

\section{Introduction}

The research about Hinduism Humanity at Ratu Bagus Ashram in the Muncan village, Selat district, Karangasem regency fundamentally analyze about synergism between the religion practice and humanity service. All of the religion believers believe that religion as the sacred revelation of God in order to a human being is able to behave right based on His-guide. If this is true, so the religion is really significant and functional to build the harmony between human being who belong to a religion. But the fact shows that there are many crimes or abuses that act on behalf of one religion that often happens nowadays in all part of countries which the community 'admits' to respect the high values of his religion. Ziaulhak (2011) stated that the relationship between one religion and another religion is really sensitive, so it needs serious effort to transform this relationship become harmony relationship which is dynamic, open and inclusive. It is also expected that the religion can be placed in the right humanism platform, such as; how to practice religion or theology rule which able to appreciate both the practice of religion and practice the humanity principle. The humanity theology is built as the basic of intimate meeting point of 
religions relationship, because there is no the religion without the humanity principle, in other side the value of humanity will dry without the religion concept.

Based on the background of the study stated above the research is interesting to do and it is interesting to spread it because Ratu Bagus Ashram is the religion community of Hinduism in Bali which tries to dedicate his religion teaching which revealed directly by God and it must be practiced in daily life for the benefit of human being. The religion which emphasize on the faith or belief must be in accordance with the humanity sides, if only someone behave humanists, it is worthy called as someone who has religion or religious person. The religion and humanity is one unity totally or integrate each other, like two sides of coin which is different but cannot be separated. The community of Ratu Bagus Ashram emphasizes the importance of religion service in the form of humanity service, it means that praying humble before God is something good, but still has dirty mind and bad behavior and act criminal or anarchist to another people; it will lose the quality of praying itself. The humble feeling and mind in doing praying or offering must be followed with deep feeling and conscience to do humanity service. God intrisically is perfect, so it doesn't need to be defended "allout" by the human being or giving service or offering to much more than human capacity, because the main duty of human being is always share and care to another people and their environment.

Based on the background of study stated above, the researcher formulates some problems as follows: (1) Why was Ratu Bagus Ashram at Muncan village, Selat district, Karangasem regency founded?; (2) How is the implementation of Hinduism humanity at Ratu Bagus Ashram community in the Muncan village, Selat district, Karangasem regency?: (3) How is the implication of Hinduism humanity at Ratu Bagus Ashram community in the Muncan village, Selat district, Karangasem regency? The research is intended to (a) To describe the reason why Ratu Bagus Ashram at Muncan village, Selat district, Karangasem regency was founded; (b) To reveal the implementation of Hinduism humanity at Ratu Bagus Ashram community in Muncan village, Selat district, Karangasem regency; (c) To understand the implication of Hinduism humanity at Ratu Bagus Ashram community in Muncan village, Selat district, Karangasem regency

The third problems will be analyzed by some theories as follows: (1) Social Exchange Theory; (2) The Critical Theory; and (3) The Hermeneutics Theory. First, Theory of Social Exchange is used to analyze the pattern of social relationship, both individual like the relationship among the students of Ashram and institutional such as; the relationship between Ratu Bagus Ashram and the society around them, and also humanity service at the community of Ratu Bagus Ashram; Second, Critical Theory; the theory is able to give strenghtening or affirmation on the analysis of religion and humanity, because all the time the religion in all parts of the world is regarded very exclusive and it sometime has violence, the critical theory try to present criticism to the phenomenon that happens nowadays in our daily life; Third, The Hermeneutic Theory; The theory is used in many things, especially which related with the religion texts in the scripture of Veda (and also another Hinduism scripture). The research actually doesn't use 
the texts as subject or object the research, but it uses the real religion practice in daily life of the community of Ratu Bagus Ashram at Muncan village. However when the researcher investigates the problems about the base concept of religion practice and humanity service at Ratu Bagus Ashram, the researcher must use the religion texts in the scripture, so the importance of Hermeneutic theory becomes so important or significance to use.

In collecting valid data in the research, the researcher uses some method as follows: (1) Observation; (2) Interview; (3) Study of Literature; and (4) Study of Document. First, Observation; The research uses unstructured observation and non-participant observation. Unstructured observation is the observation which held without limitation of object that has done in the real location. Non-participant observation is the observation which an observer doesn't involve his self in the activity of his object, an observer just observe the activities the object has done at first glance; Second, Interview; The technique of interview used in the research is opened interview and in-depth interview. The opened interview is done so we get the information wholly from the respondent in waking state and they know the meaning and the purpose of the interview. In-depth interview refers to interview guidelines that have prepared before. The data collection from interview is about the understanding of religion practice, bio-energy meditation, shaking, tutuh, and humanity service, such as; mass ngaben (mass cremation), en masse potong gigi ceremony, scholarship, etc. Third, Study of Literature; Study of literature can be done to get secondary data through; literature, the result of literature, the activities in Ashram, scientific magazine, and relevant journal with the topic of the research, magazine, relevant books, the result of seminar, scientific articles, informant or native speaker, decision letter and internet; Fourth, Study of Document; Study of document in the research, such as; note, transcript, photo, inscription, and another document which related with the existence of Ratu Bagus Ashram at Muncan village, Selat district, Karangasem regency. The main character of this data is unlimited by space and time so it gives opportunity to the researcher to know all things that had done in ancient time. The collection of data in the form of writing called as document in broad sense belongs to monument, artifact, photo, disc, CD, hard disk, flash disk, and etc.

\section{Result and Discussion}

\subsection{General Description and Research Location.}

Ratu Bagus Ashram located at Muncan village, Selat district, Karagasem regency. In the term of geography Muncan village has boundary with some areas; in the north part of Muncan village is Sebudi village, in the east part is the river of Kauh Tukad (Peringsari village), in the south part is Sangkan Gunung village, Sidemen district and in the west part is the river of Yeh Sah, Rendang district. The land area of Muncan village is about $10.64 \mathrm{~km} 2$, which dominated with paddy field and dry field. Pakraman village of Muncan consists of 13 Banjars. Muncan village has middle weathers or climate and the rainfall is about 2.000-3.000 $\mathrm{mm}$ in a year. Land use of Muncan village, the most part dominated by agriculture, especially in the south part. Most of the population have profession as farmer, farming 
labor, sand labor, craftsmen (carpenter, stonemason and craftsmen of bamboo), but just little of them is civil servant, private employees, and national army or police.

Ratu Bagus Ashram was founded at 1980 by Ida Pandita Mpu Parama Daksa Nata Ratu Bagus. He is also the main character or spiritual teacher at the Ashram. Initially it was founded as the small, simple and humble Ashram; the purpose of the founding of the Ashram is as the place of tirthayatra/spiritual pilgrimage. At 1993 Ashram has great development, which the physic development begins to grow well; the inhabitant of Ashram is more increase, from the domestic and overseas or abroad. The guests usually stay in the Ashram is about 5-6 days. The first program of Ashram is to make the life is full of love, gladness, amusement, and happiness using the exercise of meditation of bio energy or shaking, laugher and tutuh.

I Ketut Widnya is nickname of Ida Pandita Mpu Parama Daksa Nata Ratu Bagus, he born at Sangging-Gianyar at $26^{\text {th }}$ November 1949. In the research he was written with the name of Ratu Bagus. Since he was born he had shown social sensitivity and sympathy to the human suffering. According to paranormal stated that, "The little boy of I Ketut Widnya is the manifestation of holy person at ancient time, so it is the reason since he was born he always cry because he realize that the birth is actually a suffering (samsara)". Then the paranormal told to the parent of I Ketut Widnya that "After 42 days he will stop to cry". The statement of the paranormal was true, after Ratu Bagus had 42 days old, he stopped to cry. He growth as the another boy, then he studied at the school as common boy. The difference is the litttle boy of Ratu Bagus on that time is about his attention, empathy, caring and tolerance to the sorrow or the suffering of another people around him.

Ratu Bagus teaches the easiest meditation system. Every person must not do asana or special posture. He also doesn't force someone do special posture or movement. Every person who comes to Ashram just does any posture or movement that he can do, the important thing is just move, because the movement is actually come from their self. The movement in the Bio Energy Meditation of Ratu Bagus called as shaking that means shake or swing the body until create vibration. The method of shaking is identical with the way to wake up the sleep snake in the basket (wakul). If we shake the wakul or the basket, so the snake will wake up. It is same as kundalini which live or stay in human body will arouse if the body shaken with fast movement and full concentration. The concentration will add the speed of body vibration so the body looks like vibrate itself and it never stop.

Ratu Bagus Ashram provides some facilities of Ashram, so it makes the domestic or foreign visitors will feel comfortable to stay in the Ashram. The visitors, the guest, or the student or sisya who lived in Bali, they are certain not problem about the place, because they are accustomed live naturally and unite with the nature or the environment. But for the guests and the students (sisya) who come from abroad and they want to live for a long time, such as one week, two week, or even three months, so they need home stay. There are some homes stay were already built, were still built and will be built. It is because the guests and the students (sisya) from some countries in every day more increases, more people come to Ratu Bagus Ashram, so the 
important facility they think to be built is hall/place for exercise with the supported facility such as; sound system, toilet, and place of tutuh/ injection to drain all diseases or sickness in the organ of body. The another facilities such honesty canteen to some business activities for selling the accessories which has art touch, feeling and energy from Ratu Bagus, restaurant, kitchen, office room, classroom or meeting room, parking area and another facilities to do agnihotra are provided.

Anyone who comes to Ashram will meet many communities people at Ratu Bagus Ashram. The communities is just not consist of the student or sisya Ratu Bagus who come from outside part of Ashram, but also there are many students or sisya who lived in the Ashram, there is also some students or sisya who married or household and they have children who live in some days in the Ashram. Some students or sisya who lived settle in the Ashram will be given the special rules and tasks based on the talent or skill and their ability. There is someone who responsible to manage the cleanliness of the park, garden and there is someone who manage the restaurant. Every day the Ashram looks so crowded, because some students or sisya who lived in the Ashram is pretty much, and also some students or sisya who comes for just one day without stay in at the Ashram. Local residents who lived in Ashram get the duty to manage the Ashram as the management of Ashram, Balinese people who want come to Ashram according to his own purpose, Indonesian people who sometime lived in Ashram, and foreigners or tourists who spend the night or stay in the Ashram and Ratu Bagus with his wife lived together in Ashram.

The Program of Bio Energy
Meditation of Ratu Bagus is held every day from morning until night. When Ratu Bagus lives in the Ashram, so he himself train and guide the students or sisya. When he is not stay in the Ashram, so the advanced student of him (like the teacher assistance) who mandated to lead and keep watches the exercise. Because of that, in anytime every people come to Ashram, they will see some students or sisya doing shaking or meditation of Bio Energy. Whoever wants to join the exercise always served place and time at Ashram to practice.

\subsection{The Reason the Foundation of Ratu Bagus Ashram at Muncan village, Selat District, Karangasem Regency.}

First; To build the community who healthy in spiritual and physic. Every person wishes the health because the health is everything for everyone. The word 'health' is the balance condition which dynamic between the shape and the function of the body and some factors which affect it. Healthy in physic and spiritual is the important thing in this life. Ratu Bagus stated the human being without good health will not able to develop or grow well in physic and spiritual. Among some physical need, the health is the highest important. By the healthy physic and mental, all needs will be fulfilled, but in other side, even though we have all needs and all wishes fulfilled, but if our body and mental is sick, so all things are nothing in this life. Because of that, he always suggests and invites everyone to come to Ashram to take exercise of Bio-Energy Meditation, doing shaking or laugher. If all activities in this Ashram got nothing to cure the diseases or sickness, so he will do tutuh or injection because tutuh or injection will help the organ 
of our body to open the blockages, so the diseases or sickness can be went out from sneezing, throw up or gag, sweat, etc.

Second; To build religious society. Initially the Ashram was found by Ratu Bagus to make the religious society. The human being is able to exist and enjoy anything, it is because the mercy or the blessing of God. Because of that, Ratu Bagus suggests all students or sisya before doing shaking, it is first to say the holy sentence or holy greeting to the manifestation of God with the Mantram: Om Swastyastu Ratu Bagus, Om Swastyastu Bhatara Lingsir Ring Gunung Agung, dan Om Swastyastu Bhatara Surya. The third Mantram which made by Ratu Bagus was believed as the holy greeting to the manifestation of God in order to guide someone in exercise. The holy greeting to Ratu Bagus with mantram "Om Swastyastu Ratu Bagus", shows that a student or sisya intends to surrender his self absolutely to Ratu Bagus as teacher spiritual. The holy greeting of mantram "Om Swastyastu Bhatara Lingsir ring Gunung Agung", intended to the manifestation of God as the holy power or spiritual power who dominate Bali island who reside at the top mount Agung, and greeting mantram "Om Swastyastu Bhatara Surya" is intended to ask guidance to the God in the manifestation as Dewa Surya, so He will give someone a light to overcome the darkness caused by the ignorance to bright light.

Third; To inspires about the spiritual as the most important in our life (in Indonesian called Spiritual Modal Segalanya or SMS. To build Ashram is one most suitable way to state this truth. The slogan of Ratu Bagus which is really popular nowadays is "Spiritual Modal Segalanya (SMS)" means the spiritual as the most important in our life.
It is so simple, He states that our body is nothing, but the soul or the spiritual is the esential for our life. The soul or the spirit is the self identity for everyone. It is just someone who understand the soul which realize his self identity. It is the reason why someone feels sick or why someone becomes poor, the answer is because he doesn't have the soul realization. It is also cause some people feel sad and sorrow in their life, it is because they dont have soul realization. If someone just caring about his body or physic realization so the happiness is far away in his life. The pysic realization will cause sad and happy change in every moment. He always emphasize to their students or sisya to understanding his self. It is the meaning of the spiritual as the important thing in our life. Everybody must learn spiritual, because spiritual life is the source of the nature or the universe. Before this universe is created, a long time ago this universal lived ini spiritual realm, that is the womb of God who called as hiranyagarbha. From the spiritual realm then appeared the universe to manifested itself in physic realm. Someone who learn deeply about the science system of Raja Yoga, it is absolut to arouse the kundalini because the sacret of the universe and its part (makrokosmos dan mikrokosmos) is in the center of kundalini realization or the center of hot crater which Devi Kundalini in the form of Devi who is the ruler of snake who become the key for the this universe. The way to arouse or wake up Devi Kundalini from hermahasamadhi who reside in muladhara chakra, in order to able to spread the hot energy to all parts of body by using the shaking. This way is same as to switch on the machine of motorcycle on the key button on the machine of diesel. When the key of 
motorcycle is activated, so all body of motorcycle and the machine will vibrate, while the machine is vibrating the sirculation system of water, AC, the fuel will funtction simultantly and then the mud which stick on the body of motorcycle will fall in down. It is same as the method of shaking in Bio Energy meditation, which is finally able to wake up or arise the soul realization

\subsection{The Implementation of Hinduism} Humanity at the Community of Ratu Bagus Ashram in the Muncan Village, Selat District, Karangasem Regency.

First; To create peace and happiness. The Hinduism humanity implementation at Ratu Bagus Ashram adopts the Hinduism teachings, such as; the teachings of Tri Kaya Parisudha, Tat Twam Asi, Catur Paramitha, Catur Guru, Catur Purusa Arta, Wasudeva Kutumbakam, and many more of Hinduism teaching which suitable with humanity concept. The teaching is implemented by inhabitant of Ashram in their daily life, as well as the people who intense to practice Meditation at Ratu Bagus Ashram. They are suggested to see inside their self, to find happiness and peace in their self. When they use the intelligence and the feeling, so the peace will be aroused which expected useful or significant in their life. There are five main aspects which can be the source of true happiness, such as: (1) to create the positive relationship with another people. The positive relationship is not just has a friend, couple or soul mate or children. The status of marriage and the ownership of children is not guarantee or ensure the happiness of someone; (2) the absolute engagement. It is means how someone engages his self absolutely to the job that he has. The absolute engagement is not just for the carrier, but also in the another activities such as hobby and activities with family. The absolute engagement needs active participation from someone who does it. To engage his self absolutely, it is not just the physic which does some activities, but also their heart and mind also engage absolutely; (3) find the meaning in our daily life. In the absolute engagement and positive relationship with another people will implicit the way to get happiness, so find the meaning of every activity which have done; (4) be optimistic but still realistic. The result of research stated that someone who always optimistic overcome his life more quickly to find happiness than someone who always pessimist in his life. They are not anxious to live and they are auspicious; (5) become someone who has resilient. Someone who is happy, it is not means that he is never feel the sadness or sorrow because the happiness is not depend on how many interesting events he has, but also as far as he has resilient, the ability to get up or survive from the worse events or incidents in his life.

To create feeling of peace and happy started from: (1) Peace and Happy in our self. Peace and happy which must be made at the first is make our self happy and peace, so the communities which made by us automatically become happy and peace. The peace and happiness of the communities or societies is the reflection of the happiness and peace of the individual who support them. The peace of mind becomes the base thing to keep the feeling of peace in our self. All troubles in our self become negative energy which contributes to the world destruction, and all social troubles will contribute to lose peace feeling in our self. So, Djajendra (2013), advised: (a) Found or look for the silence or 
the stillness to contemplate the way to get peace in our self; (b) Educate our emotional so we can live in the peace of mind; (c) Prepare our personality to receive the life reality to be more sincere and honest; and (d) Make our self as the energy booster which give peace in our self, and for the life around us. Make our self as the good energy who contributes to all life and the life in our earth;

(2) Happy and Peace for the Community. The peace community is the quiet community, who don't like violence and hostility. The happiness community is the community who feel satisfy enough to the need of physic and spiritual, such as; clothing, foods and houses, education, healthy, entertainment, the freedom to do religion service, the freedom to gather, the freedom to give opinion, law protection, the protection in old age, etc. There is no orderliness if there is no the peace, and otherwise there is no peace if the needs of physic and spiritual are not balance. Ratu Bagus explained, "The happy and peace community is begun with the individuals or personals who support the community with happiness and peace in their self. The happy and peace community is the consequence of happiness and peace which felt by the individual or the personal. Because of that, all people must wish to do the competition to make the peace and happiness in their self, so the community which made by them around them also feels happy and peace"; and (3) Happy and Peace for the Universe. The method of Bio Energy Meditation of Ratu Bagus in principle tries to pray so the universe move based on the law of nature or as they are. With Move the body and soul, make the negative molecules in around us slowly will be neutralized and changed be positive energy. The negative molecules which dangerous will be neutralized by the vibration that produced by someone who have meditation. The universe defined as the space and time which all energy and material mixed or united. The universe is sometime called as the cosmos or mayapada. The existentence of the universe have learned by human being since a long time ago. Time to time, as walk as the development the human mind and it is followed with the advance of technology, the point of view to the universe is more advance. According to the Hinduism cosmology, this universe can be full with peace and happiness if the material of prakerti composition has the realization.

Second; The poverty alleviation and economy recovery of the community. One of the important humanity actualization which becomes the main agenda of the Ashram is the effort to alleviate the poverty. The poverty is a social condition which must be handled well. The desire and intention to alleviate the poverty is kind, but if this is not done well, so it will be nothing or useless. Ratu Bagus explained: "The intrinsic or the real poverty in the community is just not material. When we see around us, all object can be seen by the eyes, listened by ears, touched by the skin, smelled by nose and tasted by the tongue is all about material. The real poverty is mental poverty. When the mental is poor, so the life is really poor, but if the mental is rich, even though someone has little material, it is not a problem". Because of that, the program of alleviation of poverty which has done by Ashram is integral or absolute. For the inhabitant of Ashram who have not asset at all to live, they can use the property of Ashram. While they live in the Ashram, they also practice meditation to reinforce their mental. After their mental are intense or vigorous, 
slowly they find their swadharmanya. If their swadharma is found so they know what they must do. When they know what they must do so they have desire to do the activity itself. When they have desire to do activity so they will work hard. If they already work hard, slowly he will get the result. Step by step they will able to fulfill his need of life so their need fulfilled enough or become rich. Because of that, Ashram tries to alleviate the poverty by two sides, give the help such as the material as the first step, and then educate the mental so become more intense or vigorous, so they becomes independent.

The existence of Ratu Bagus Ashram in the poverty alleviation and economy recovery are: (1) Giving scholarship. One of humanity activity program done by the Ashram to alleviate the poverty is giving the scholarship to the children of Ashram who lived in Ashram or outside the Ashram and the scholarship for the student in the university or college. They get scholarship until graduated. The scholarship such as money will be given for personal, student or student of university to continue the education they pass. The purpose of giving scholarship is to support the advance education, the equalization of the opportunity in learning for the student and the student of university who have a great achievement, but they don't have enough money to continue their study. To encourage or support and survive the spirit of learning of the student and the university student so they are able to keep their achievement and they are eager to complete their study. The Ashram also want to give motivation to the student and university student to compete in getting the high academic achievement and non-academic achievement, so it can produce the potential human source of Indonesia in the future; (2) Free Foodstuff and Houses. Foodstuff means food and drink. Foodstuff is main needs that really needed by every human being. Without foodstuff, it is certain that the human being cannot survive to live; the foodstuff is also function as the source of nutrition for of human body grows. Because of that the worthy or the proper and the healthy food is the life needed for everyone since a long time ago, now and until the future or in the doomsday. The foodstuff consists of nine staff and staple (in Indonesian called as "sembako" such as: rice, sago, corn, sugar, vegetables and fruits, meats, fried oil and margarines, milk, egg, kerosene/LPG, and iodized and sodium salt). The Ashram gives free foods and houses for the inhabitant of Ashram who still poor and lived in the Ashram; (3) Mass Ngaben No Cost (Mass cremation). Ratu Bagus Ashram have done some ceremonies of Pitrayajña which the participants don't give the fee or with little fee than the common ngaben. This is the form of service to poor community who still has sawa or ancestors who were not joined ngaben ceremony. In order to they can make the ceremony for the sawa, the Ashram initiatives to do mass ngaben no costs. Even at mass ngaben, the foreigner students (sisya) also join to do the activities. They join the activities means that they also participate to make ceremony of sawa they have. Symbolically they guide or nuntun the spirit from the abroad to Ashram in Muncan to be made the ceremony. The ceremony or ritual of Pitrayajña generally just done by Hinduism, but at Ratu Bagus Ashram, the participation of foreigner in the ceremony of Pitrayajña is unique, because formally they are not Hindu, but they active to participate in 
all parts of ceremony Pitrayajña, and also join the ceremony of mass Ngaben, Mamukur, and Ngalinggihang Dewa Hyang at Pakraman Village of Muncan, Selat distrrict and Karangasem regency-Bali, which held at 2009 ago; (4) The Foundation of Cooperative. Ashram Ratu Bagus manage the micro finance cooperative which called with the name "Koperasi Giri Murti", this cooperative is active in the micro finance specially in saving and lending the money for the costumer or the community around the ashram who want to do productive business like to buy a cow for the farming or another urgent need. This cooperative managed by Ashram, it is legal cooperative and monitored regularly by the government of Karangasem regency. The micro finance cooperative is the cooperative which service saving products or deposits and money lending for the members. The fixed term deposit is the same amount of money for every member that must be paid by the members to the cooperative when they become the member of the cooperative. The fixed term deposit cannot be taken as long as someone becomes the member of cooperative. The fixed term deposit is amount of money that must be paid by the member of cooperative in the period of time and certain opportunity. The fixed term deposit cannot be taken as long as someone still becomes the member of cooperative. Third; The Health Service. The Health service which held in Ratu Bagus Ashram is the holistic service, which every person want to get treatment or medication in the Ashram, his sickness will be cured, and also he will be invited to know the sickness and then the sickness is withdrawn until the root in his body. After that he will be invited to live health, in physic and spiritual with doing shaking as one method of self concentration and transformation. Shaking will return the cheeriness, joy and happiness that very long time have lost, using shaking someone is able to find the love and finally give the way in order to someone feels the life transforming experience. At the firstly, he must stay in the Ashram at least for 5 days to build the relationship with sacred fire in his self, then he is able to wake up his inner capacity to heal his self. Then he can produce curing process.

The Health Service which held in Ratu Bagus Ashram as follows: (1) The Traditional Treatment or Tutuh. Ratu Bagus Ashram gives the traditional treatment or tutuh of tobacco to cure many kinds of sickness. Tutuh is given to the patients to stimulate the body system which cannot function well. Tutuh is done while doing shaking. The main instrument to treatment of tutuh is tobacco, tobacco is seasoning agricultural product which doesn't belong to the food commodities, but it is plantation commodities. Furthermore it is as the material of cigarette, the tobacco also can be chewed. The secondary metabolite contain in the tobacco is useful as the pesticide and raw material of medicine. Tutuh is important in the practice of Bio Energy Meditation, because the disease in human body cannot be excreted out of the body because the body organ is not function well or abnormal. Because of that, it is needed to help the body organ to excrete the diseases. One of natural example is when our organ in the nose is normal, if there is the virus or bacteria come in, so that the nose spontaneously will sneeze. But when the sensitivity of our nose is lesser caused by the blockage, so someone is difficult to sneezing. To throw out the germs, it needs the booster or stimuli instrument of 
tutuh which use the water of tobacco that served in such a way so in seconds, someone who get tutuh will sneezing, gag, cough, etc, as the sign that the disease is forced to go out. When people get tutuh they usually gag continuously, so it needs the special place. It is the reason why the place of tutuh located on the back side of center or the center of garden Bio Energy meditation in Ratu Bagus. (2) Shaking. Ratu Bagus Ashram teaches about the easiest meditation system. Every person doesn't need do asana or special posture. He is also not requires someone do special movement. Every person who come will do any posture or movement that they can do, the important thing they move, because the real movement is come from his self. The movement in the Bio Energy Meditation system is called as shaking. Shaking means shake movement or swing the body to make vibration. The method of shaking is identical like to wake up the snake which sleep in the basket or wakul. To shake the basket or wakul make the snake wake up. It is same as kundalini will wake up if the human body shaken with fast movement and concentration of mind. The concentration of mind will add the speed of body vibration so the body looks like vibrate by itself and never stop. So the activity of movement which called as shaking is the philosophy of Bio Energi Meditation system. The philosophy is suitable with the existence of world which kept by the sistem of movement or rotation which symbolized with the dance of Shivanataraja or the dance of Shivatandava. This universe vibrate, it is identical with the movement of dance Shivanataraja/Shivatandava, it is same as the system of Bio Energy Meditation which take the philosophy of movement as the source of electric energy booster at the universe (mikrocosmos/human body) which hide in the base of muladhara chakra. So the Bio Energy meditation is the system of body exercise which harmony with the law natural principle. (3) Laugher. Laugher is the sound expression (written $h a h a h a$ ), or it is the reflection of gladness or joy. Laugher is part of human behavior which normally the result of human mind which help human being to clear the social life condition and reflect the emotion of conversation. But sometime the laugher is the way to hide the deep sadness, which cannot be express with the words. Laugher have believed by the experts since a long time ago which is good for our healthy, it is certain that laugher for good thing or has positive meaning. Laugher can help someone feel better energy and fresh, because laugher can increase the amount of oxygen and release the endorphin, such as the hormone of feel good which make someone feels happy.

Ratu Bagus (2012: 66), said that "The teaching of Ashram is really easy, but sometime difficult to receive it. It is like the teaching of laugher. This is the sacred learning for the happiness. Someone who is always laugh naturally from his heart, so he will able to feel happy. Because of that we must laugh every day. Laugher will remove the stress. If we laugh so the new cell of our body organ will recreate so we are looked young. It is also spiritually, laugher is also able to move cakra-cakra". The advantage of laugher sometime thought unimportant or trivial by some people and called it doesn't have function for the health. Some people guess that laugher is just release exhausted feeling in a moment. But the advantage of laugher is more than that, laugher also has significant in the healthy which not realized by some people. Our life actually always full 
of problems, but it is better if someone face it without sullen or glum feeling, because sullen or glum feeling can make the new problem in our life. There are some advantages of laugher which directly felt by someone, such as; (a) Be young; (b) Has long life; (c) Has better feeling; (d) Laugher can change the bad mood become good mood; (e) Laugher prevents stress; (f) Remove the sadness; (g) Smooth the blood current; (h) Increase self confidence; (i) Give positive thinking; (j) The heart is more healthy; (k) Increase the memory, and etc.

\subsection{The Implication of Hinduism Humanity at the Community of Ratu Bagus Ashram in the Muncan Village, Selat District, Karangasem Regency.}

First; Self Development of Students (Sisya). The Hinduism humanity Implication at Ratu Bagus Ashram more emphasized to the self development of students or sisya, because the values is useful or significant for the community of Ashram and the society at large. To live together, respect each other, community self-help or mutual cooperation, learning together, doing sadhana with the exercise of shaking regularly, listen the preaching of teacher or guru (Ratu Bagus) are the application of Hinduism humanity values. In Hinduism concept are some wonderful teachings; Tri Kaya Parisudha, Catur Paramita, Catur Guru, Catur Purusa Artha, Tat Twam Asi, and at subasita Veda, such as; Wasudeva Kutumbakam”.

The implication of Hinduism teaching in the community of Ratu Bagus Ashram in the Muncan village, Selat district, Karangasem regency, as follows: (1) Spiritual Improvement. Ashram teaches the concept of "Spiritual Modal Segalanya (SMS)" which translated as "Spiritual is the most important thing in our life", self change to spiritual will happen if there is positive suggestion in our self. Moreover, the important thing is we are able to find our real self existence. If someone is not realized yet his real self existence, so it is difficult for him to get advance. Because of that, using shaking, Ratu Bagus sees the true potential which can be got by everyone. When the spiritual dimension appears, so self existence can be found, so every impossible thing will be possible to do. The mind is limited, but the soul is perfect. Someone who has spiritual improvement will feel many surprises in his life; (2) Health Improvement. Health is the investment which supports the economy development and has important role to overcome the poverty. The development of health must be seen as an investment to increase the quality of human sources. To measure "Indeks Pembangunan Manusia (IPM)" which translated as "Index of Human Development", health is one of the main components than the education and the income. Health is prosperous condition of body, soul and social which make everyone live more productive in social and economy. In this case the Ashram always advise everyone to practice the Bio Energy Meditation so the health of physic and spiritual will be kept well, the good health make easier someone to find the real existence of his self. Real self existence is the soul. It is the soul as the greatest one than everything. Something is needed to get health improvement is find again the real self, that is the soul itself; (3) Financial Improvement. The financial improvement affected by two factors such as the income and outcome. Initially the financial calculation is really easy, the income subtracted with the outcome, 
the difficult one is manage in order to the income is bigger than the outcome. There are many ways to get surplus in income, such as: First, economical or thrifty (reduce the outcome); Second, add the income; Third, do both of them, like thrifty and add the income. Actually reduce the cost of living is easier than add the income, because the cost of living is the kind of self control, but add the income involve another or the third person. Based on the consideration above so Ratu Bagus has ability to clear someone vibration so his fortune or live hood is better. But the most effective way to do is always feel satisfy and thanks to God, that is the essence and the key of happiness itself. Whatever we get on this day is the highest blessing or the mercy of God, so that we must be gratitude to God, and we must always keep practice to spread love to another; (4) The Improvement of Social Realization. To understand the concept of social realization, firstly we must understand about interpersonal intelligence that means; the ability to solve the problem and produce the product in different setting in real life. Interpersonal intelligence will appear if someone has ability to understand the situation and condition of another person. The situation and condition can be found if there is direct struggle in society life. The social realization is one concrete form of interpersonal intelligence. According to Ratu Bagus, the way to grow the social realization is love. Love is able to unite human relationship one with another. Love is able knock the door of heart of someone else, and everyone in this world needs love. With love the community will be arranged and it is able to keep the harmony life that is the true love; (5) The Improvement of Intellectual, Emotional, and Spiritual Intelligence.
$\mathrm{IQ}=$ intelligence quotient is placed on the part of Cortex (the skin of brain). The intelligence is seen on the ability of someone to count, to make analogy, imagine and has the capacity to create or has innovation. Ratu Bagus said the brain intelligence can be maximized by the exercise of shaking. While doing shaking someone feels trance. When someone feels trance, the mind is not work, the mind rests totally, although just a moment, but it is able to refresh all brain system so the brain is more arranged or ordered and more effective to work again. Whoever who practice the technique of Bio Energy Meditation regularly so automatically the intelligence of quotient will rise, because the cells in the brain nerves repaired and cleaned continuously.

$\mathrm{EQ}=$ Emotional Quotient is the ability of someone to receive, estimate, manage and control his emotion and the emotion of another people around him. In this case the emotional quotient refers to the feeling of information about the relationship. But the intelligence quotient refers to the capacity to giving valid reason about the relationship. EQ (Emotional Quotient) is also as important as the intelligence quotient (IQ), Emotional quotient is two time more important than intelligence quotient to contribute for the success of someone. Ratu Bagus in the method of his Bio Energy also develop the effective model to increase the emotional quotient of someone. When the soul works well, the mind will stop to work so the emotional of someone will grow well. They begin to have empathy, love, deep love, mercy and realization about the importance of sharing feeling. If someone takes the exercise of soul regularly so the emotional quotient will raise automatically. It means that they 
can make a good relationship with everyone easily, because someone who have emotional quotient, his energy will easy to spread in his self.

$\mathrm{SQ}=$ Spiritual Quotients is the essence of all intelligence. This intelligence is used to overcome the problem related with spiritual norms and values. This intelligence will drive or guide someone to get real happiness. Ratu Bagus considers that spiritual intelligence is direct effect of the practice of Bio Energy Meditation. When the soul works, the gap between one with other will vanish or unite become one. When they are able to feel the unity with other, their realization also develops and they can feel that they are not different with another. This is the spiritual quotient in its top position than other quotients, someone who have spiritual quotient will able to think positively to become better person, become intact personality, get up from failure, not trapped in the sorrow and able to become motivator for his self and another person, so he becomes wise person to face life and overcome the problems in this life.

Second; The Improvement of Social Culture Relationship. The social-culture relationship at the Ashram community is more emphasized to the rule how to think, to act and see another people. Someone who has more knowledge, money and wealth usually has behaviors who want to be served. But when someone lives in the Ashram, whoever they are, even though they have money or not, they are treated same. Doing the job together, there is no greater person or less great, rich and poor people. Becoming the servant, someone invited to rise or wake up spiritually. The culture that they want is how to live without ego. The culture without ego is actually makes the world is full with peace and creates the behavior to respect each other. In the context of Ashram the improvement of social-cultural relationship means the relationship between West culture and East culture. East culture has the great and wonderful spiritual, but West culture has good management system. The merging of two cultures in the community of Ashram make the Ashram unites and develops well and positively. The west culture as the representation of intellectual and East culture is the representation of emotional, when there is relationship of West and East, so the Ashram walk effectively and efficient. Since a long time ago if the foreigner or West people come, they must be served. But when they are at Ashram, they becomes the servant, such as; serve his self and serve Ashram well, such as wash dishes, cook for his need and the guests, mob or clean the floor, clean the leftovers food, etc.

The real representation of social culture relationship in the community of Ratu Bagus Ashram as follows: (1) Ashram participate actively in Social Activity. Social activity at the community of Ashram is the form of social sensitivity to another individual or community who has bad condition. The bad condition here means less of clothes, houses, or healthy in physic and mental which caused by some conditions. For example, disaster, physical defect or disable people, or financial problem. The social activity can be done using many kinds activity by some group. The activities such as social service, social visiting, free check up, and also another activity such as Indonesian teaching program which is the part of social sensitivity of the Ashram community. In other side, the Ashram community also joins the activity in 
every event which held at Muncan village, and also at Selat district, for example; fun walk to celebrate the historic day, cleaning program, community self-help to build public place, join activity of ngayah (religion service at pura or temple) to celebrate odalan (religion ceremony) in some pura around the Ashram and becomes the donator of some social activities, in Muncan village or Selat district. Ashram also gives the financial helps or aids to personal or individual who needs for continue the education or another needs; (2) The Community participate actively in the ashram activity. The Ashram community participates actively in the activity of the society around the Ashram, in other side the society of Muncan village also participates actively in the Ashram activity. There is "symbiosis of mutualism", or the activity which supports each other and gives the benefit to both of them. For example in the celebration of Ashram anniversary, the village officer (pecalang) and the youngsters around Ashram also participate to do ngayah (religion service). Moreover the group of traditional song and music (sekaa santi and tabuh) also participate to celebrate the anniversary. When the Ashram intends to do the ritual or ceremony of mass ngaben, the society around is also enthusiastic to join. Even they have corpse which must be hold a ceremony or ritual of ngaben (sawa) and also even for the inhabitant who doesn't have sawa or just doing ngayah. They are enthusiastic to join the activity of Ashram. According to Ratu Bagus, it is really important because the activity or event will be success and move smoothly if we are understands each other to do some activities together and support each other. There is intensive relationship and feeling to help each other, so there are any obstacles for us; (3) Symbiosis of Mutualism between Ashram and the Society. Symbiosis of Mutualism is the biology term to call two species relationship which benefit each other, the relationship between two different kinds of creatures and they give benefit each other. For example, the relationship between bee and flower, when bee sucks the essence of flower, the bee gets benefit because it gets the nectar, then flower also get the benefit in the process of pollination. Another example is the relationship between buffalo and the bird of mynas or starling which the buffalo get the benefit because the louse is eaten by mynas or starlings, and mynas or starling also get the benefit because it gets the louse as its food. The concept of mutualism symbiosis is really benefit between the Ashram and the around society. It is proven that every event which held by both of them, Ashram and the society are success. The success of them is related with the good relationship between the Ashram and the community. They feel the benefit together. The real example when there is ceremony or ritual (odalan) at Pura in Muncan village, Ashram always present to give financial support (dana punia), so the society are helped to decrease the amount money or thing that must be paid to Pura (mepesuan). With the financial support from Ashram, all society gets the benefit. As the reply, when the Ashram held the event, such as Ratu Bagus anniversary and another activity, the society especially pecalang (village officer) and youngsters joins the activity (ngaturang ayah) at Ashram. With their help, Ashram gets the benefit so the hard job becomes easy to do and it has done well with maximal result.

Third; Make International Networking. To build the world full with 
happiness and peace, it needs cooperation between one man to another man so the universal realization will grow and develop well. The universal realization can be build when there is realization about the unity of all existence or all things in the universe. The realization is generally called as cosmic realization. Human realization will rise to rebuild his own cosmic realization which actually is the natural asset of human being since born. It is because the human being have contaminated with the material world so the cosmic realization trapped in the material world so the cosmic realization covered thickly by the dust of material realization. Because of that the natural realization of human being is built to make the world harmony. Then the universal realization in pragmatic level make the Internasional Networking. This realization will able to relate Ratu Bagus with all the worlds. Until now the center of Ratu Bagus have built in some countries, it is about 40 countries. The foundation of center as the place of exercise for Bio Energy Meditation of Ratu Bagus in some countries is the proof that the universal realization can relate the people to people (the relationship which penetrates the space among countries) and then they do the activities together. Using the universal realization, Ashram Ratu Bagus which centered at Muncan village have spread to all parts of the world. It can be happen because it is believed there is energy wave as the affect of their consistence to do bio energy regularly. The internasional networking is possible happen, because the cosmic energy have met them. Because of that, in order to there is good international relationship, the eksplore of the knots of energy is really important.
International Networking in the Ratu Bagus Ashram at Muncan Village as follows: (1) The Foreigner joins Shaking. It is because the cosmic energy so all thing happen, include the internasional relationship will be created, it is proven with the increase of foreigner come to Bali to join the exercise of shaking. So the instrument which relates them is shaking. Bio Energy Meditation is more popular called as shaking meditation, which is the exercise which can change the life. It is possible with the transmission of Ratu Bagus holy energy. The energy transmission is able to live the sacred fire which owned by every person (the fire of kundalini), and used to curing process, among physic, emotional, mental and spiritual. To live and get the benefit of holy energy, it is not enough just with the theory or technique, but also can be got from the regularly and seriously exercise. Ratu Bagus teaches the realization of energy is not limited on the mind, but also in the experience. The transformation to get the highest self potential will happen if negative thinking which blockage the energy have thrown away. The exercise done with shaking or swing all body (shaking). To follow the vibration of energy, so our body spontaneously will vibrate, move and turning, this exercise is simple but also it is strong. Ratu Bagus has thousands of foreigner student (sisya) from West, then they develops their networking all around the world. Every country has a group to do the exercise of Bio Energy Meditation regularly. Some countries which belong to the Ashram networking of Ratu Bagus such as: Australia, Belgium, Denmark, French, German, Netherland, Ireland, Israel, Italy, New Zealand, Spain, Sweden, Swiss, England, America, etc; (2) The Foreigner respects the 
Hinduism Tradition. When the foreigners live in the Ashram they are often use traditional clothes of Bali. Moreover when they are doing the exercise, they chant gayatri mantram and do another ritual. In the special event, like the anniversary of Ratu Bagus, the guests who live in the Ashram joins to celebrate the event by dance traditional dance of Bali, such as sendratari dance (dance drama) and another dance, they are also discipline to practice yoga. According to the testimony of Tilda Tucker (citizen of foreign country or citizen of Enggland) said that her main purpose come to Bali is to joins and learns the shaking meditation, she comes with her son, and she knows the place of Ratu Bagus Ashram in the Leaflet in one of Tourisme Object of Bali in Ubud village. Because she wants to increase the spiritual, so she decides to find more about Ratu Bagus Ashram. She enjoys the practice, especially the exercise of shaking meditation and comunity life of Ashram. All foreigner guests stated that they are interested and motiovated to join the Ashram activity, because they are sure and believe the true of yoga teaching from Ratu Bagus. One of her main purpose is spiritual awakening, as the result of Bio Energy Meditation and spiritual life at Ashram.

Fourth; The Development of Ratu Bagus Ashram. Physically the development of Ashram continuously done, there are some home stays have built, have been building, will be built because there are many guests and foreigners student (sisya) from some countries around the world increase more and more to Ratu Bagus Ashram at Muncan village. The facility is viewed important for exercise is enough fulfilled, such as; auditorium or hall or place for exercise that completed with the supporting facility such as; sound system, toilet, and place for tutuh or injection to drain the diseases in the human body. The another facilities such as the honest canteen and business activity for selling the accessories that already get the art touch, feeling and energy of Ratu Bagus, restaurant or place for eat together, kitchen, office room, classroom or meeting room, parking area and another facility to do agnihotra are also built. In the science which taught in the Ashram, Ratu Bagus as the spiritual teacher of Ashram teach two kinds of knowledge, it is because the source of the sorrow for human being according to him are: First; The ignorance because they dont have knowledge and, Second; it is because the diseases of physic and mental. To overcome the sorrow of the ignorance or darkness, so Ratu Bagus teaches the knowledge how to learn something as the common learning, and teach how to overcome the sorrow because the diseases, Ratu Bagus creates the knowledge of "Bayu Suci" (Holy Energy) or more popular called as Meditation of Bio Energy.

Fifth; Reflection. Ashram of Ratu Bagus firstly was founded at 1990 in simple condition. On that time the place of shaking exercise is small and made from simple material. Days by days, when many foreigner guests are often to come, the area of exercise slowly wider or expanded. One by one of Ashram building was built looks splendid right now. Some physic facility was built to support the guests need who want stay for longer time and more intense to practice BioEnergy Meditation. Some people see this Ashram look likes a Villa than an Ashram, because the building and the physic facility is complete. Some people think, are there a spiritual activity inside or just place for 
recreation? Based on the observations of the researcher and the result of interview from the management of Ashram or Ashram community, the spiritual activity done regularly as the first purpose the Ashram was found. Moreover the intensity of their activities is more increase. According to Ratu Bagus, the physic building which looks so splendid not cut the spiritual activity. But it is because the splendid building can make the spiritual activity will be done better. The facility of material must be used maximal to the spiritual need. The building of facility which is luxurious is intended to help the exercise of spiritual itself. Exactly the luxurious building from the outside will become the motivation to born the luxurious of our self. From the building of Ashram which is luxurious expected create someone who has great soul.

Based the explanation above, there are some reflections as follows: (1) The Glorious of Material should not blind someone to do spiritual service, but it is able to increase the spiritual life of someone; (2) Material and Spritual is a reality that should hand in hand and it is not to destroy or disturb each other; and (3) Spiritual is the life philosophy for human being, so whatever the job, profession or the behavior must harmony with the spiritual values.

Sixth; Research Invention. Based on the result of data analysis, it is found that the humanity at Ratu Bagus Ashram based on the spiritual awakening of someone. The human being since was born have brought track or trail of hate, anger, jealous, greedy etc (homo homoni lopus). All characters above will be expressed in life if someone doesn't have opportunity to develop spirituality in his life. So that, the human values such as love, non violence, truth etc which can be implemented in the society if they learn about spiritual, because the spiritual make self development awakes so he is not trapped by the negative characters. It is just spiritual which able to build the human foundation; Ratu Bagus call this description with the term "Spiritual Modal Segalanya or SMS" (which translated as the spiritual is the most important in our life).

The mission of Ashram is to introduce the spiritual as the essence of life to all parts of the world then Ratu Bagus founds a technique of meditation which is really relevant with the life of modern man which views the life from science perspective. The technique is called as "Bayu Suci" or now famous as "Bio Energi Meditation of Ratu Bagus", which scientifically the benefit or the significance is valid. Using shaking meditation to shake the body, it makes the blockage of energy will open, so it penetrates to our soul. When the soul is not blocked by the mind, someone will feel the spiritual advance. When spiritual life of someone develops so humanity feeling will grow well. They will become personality who is gentle, full with love, like to help, don't like to hurt someone else and always happy.

Based on this consideration, then Ratu Bagus Ashram develops fast in 40 countries. The students or sisya are sincere to do religion service for the development of Ashram and they are also sincere to do human service. Ashram is also continuously to do human service to them who need it. Many people who have healthy problem come to Ashram. They are served and cured with love so they can be cured. Then many people also come to Ashram because they feel the dry spiritual or thirst of spiritual life and they have many 
problems in their life. In the Ashram they are served with love so they feel the significant impacts. Ashram doing social service periodically such as blood donor, scholarship, giving help to inhabitant who live in Ashram, doing mass ngaben, mass potong gigi ceremony and another humanity activity.

Whatever done in the Ashram, principally want to make everyone aware that spiritual is the most important in our life. Using the exercise of shaking (Bio Energy Meditation of Ratu Bagus), someone will be trained to live healthy, both physic and spiritual. If they are healthy, so they have opportunity to do many things so get impacts to their economic level. The rise of love in our self will give direct impacts to the desire of help someone else so the harmony of social life will be kept well.

\section{Conclusion}

First; First; The reasons why Ratu Bagus Ashram at Muncan Village, Selat District, Karangasem Regency was founded: (1) To build the healthy society both physic and spiritual. Many people come to Ashram with many kinds of problem both physic and mental. Using the technique of Bio Energi Meditation of Ratu Bagus, most of them, even they suffer light or hard sickness which can be cured totally; (2) To build the spiritual society. It is come true by the exercise of shaking continuously. After our physic and mental are healthy, so the shaking meditation will directly affect the spiritual advance of someone; (3) To inspire the society about concept "Spiritual adalah Modal Segalanya or SMS" (spiritual as the most important in our life). The Ashram tries to confirm the society what the important of spiritual in our life. This effort is done with the philosophy or motto
"Spiritual Modal Segalanya or SMS (translated as spiritual as the most important in our life). With the essence of spiritual, whatever activity will be done successfully, because the blessing of God always support and bless us.

Second; The Hinduism Humanity Implementation at Ratu Bagus Ashram in Muncan village, Selat district, Karangasem regency are: (1) To create the feeling of happy and peace. Using shaking, the soul is awakened so his realization feel advance. The advance of realization will able to affect the point of view of someone. The view of someone will build the feeling of happy and peace, both our self or the society and the environment of the universe around us; (2) To overcome the poverty and repair the economy level of Ashram community. To make it come true, the Ashram doing some ways as follows: (a) giving scholarship to student or student of university which poor, but they have good achievement in academic; (b) facilitate the clothes and food freely for them who live in the Ashram; (c) periodically the Ashram also doing ritual or ceremony of mass ngaben, to help poor people who have sawa (corps which must be got ritual of ngaben) because the financial problem; and (d) Ashram also build cooperation so it manifest more prosperous society; (3) Health service. It is done with the exercise of shaking regularly, tutuh, and laugher. Shaking is held twice in a day in the hall of Ashram. Before shaking, it is usually the participants doing the ritual of tutuh that is put in the water of tobacco to nose to stimuli all negative energy in our body which forced to go out. The shaking activity usually is done with laugher, as the expression of happiness and peace which sourced from the soul. 
Third; The implication of Hinduism humanity at Ratu Bagus Ashram in Muncan village, Selat district, Karangasem regency are: (1) Self improvement of student or Sisya. The existence of Ashram make the society is able to feel self improvement, such as spiritual improvement, health, financial, social awakening and intellectual intelligence, emotional quotient or intelligence, social intelligence; (2) The improvement of Social Culture. This relationship happens because the Ashram actively to join the social activities in the society around Ashram. In other side, the society is sincere participate actively in the activities of Ashram. Based on this consideration, so there is the relationship which give benefit or significance each other between the society and the Ashram or it is called as "symbiosis mutualism" between the community of Ashram with society around them; (3) There is the International Networking. International networking is appeared because the consistency of the community of Ashram doing Bio Energy Meditation, this cosmic energy is able to connect Ratu Bagus with the worlds so many foreigners come to Ashram to do shaking. They do the meditation with faithfully and discipline. Moreover the foreigners also respect the Hinduism tradition. Many of them join the religion activity, chant Gayatri Mantram, use traditional cloth of Bali, and another Hinduism tradition. Another of important internasional relationship is the technique of Bio Energy Meditation of Ratu Bagus have practiced in some countries, it is about forty countries in the Europe and America who have practiced this Meditation practice; (4) The development of Ratu Bagus Ashram. This is the impacts of the increasing of foreigners who come to Ratu Bagus
Ashram at Muncan village to do the exercise of meditation, the consequence is the facilities such as home stays and another equipment continuously to be built and always to be developed.

\section{References}

Bagchi, S. S. (2017). The Great Betrayal: Potential Statelessness After Living Decades In Mother India. Vidyottama Sanatana: International Journal of Hindu Science and Religious Studies, 1(2), 122-131.

Berger, Peter L., 1992. Langit Suci Agama Sebagai Realitas Sosial. Jakarta: PT. Pustaka LP3ES Indonesia.

Berger, Peter L., dan Thomas Luckmann, 1990. Tafsir Sosial Atas Kenyataan Risalah tentang Sosiologi Pengetahuan. Jakarta: PT. Pustaka LP3ES Indonesia.

Budi-Hardiman, F., 2012. Humanisme dan Sesudahnya: Meninjau Ulang Gagasan Besar tentang Manusia. Jakarta: Gramedia.

Depdikbud, 1996. Kamus Besar Bahasa Indonesia. Jakarta: Balai Pustaka.

Donder, I Ketut, 2007. Kosmologi Hindu. Surabaya: Paramita.

Donder, I Ketut, 2009, Ida Pandita Mpu Parama Daksa Natha Ratu Bagus dan Fenomena Eksotis Kesadaran Kosmisnya. Surabaya: Paramita.

Donder, I Ketut, 2009. Meditasi Bio Energi Ratu Bagus, Meditasi Tarian Jiwa, Spiritual Holistik dan Pembangkit Kesadaran Kosmis. Karangasem: Ashram Ratu Bagus.

Erich-Fromm, 1950. Psychoanalysis and Religion. New York: Yale University Press. 
Flood, Gavin D., 1996. An Introduction to Hinduism. Cambridge: Cambridge University Press.

Harun-Yahya, 2016. Penciptaan Alam Semesta. Dalam: http://id.harunyahya.com. Diunduh: 1910-2016.

Mangunharjana, 1997. Isme-Isme Dari A Sampai Z. Yogyakarta: Kanisius.

Martin, Richard C., 2002. Pendekatan Kajian Islam dalam Studi Agama. Alih bahasa Zakiyuddin Bhaidawy, cet. Ke-2. Surakarta: Muhammadiyah University Press.

Mikkelsen, Britha, 1999. Metode Penelitian Partisipatoris dan Upaya-Upaya Pemberdayaan. Jakarta: Yayasan Obor Indonesia.

Ratu Bagus, Ida Pandita Nabe Parama Daksa Natha (Suwantana, I Gede, ed.). 2012. Butir-butir Kebijaksanaan Titian Hidup sehat dengan Meditasi BioEnergi Ratu Bagus (Ratu Vacanamritam-1). Karangasem: Ashram Ratu Bagus.

Ratu Bagus, Ida Pandita Nabe Parama Daksa Natha, 2014. Bio-Energi, Tertawa dan Pandita. Karangasem: Ashram Ratu Bagus.

Sudarsana, I. K. (2017). Interpretation Meaning of Ngaben for Krama Dadia Arya Kubontubuh Tirtha Sari Ulakan Village Karangasem District (Hindu Religious Education Perspective). Vidyottama Sanatana: International Journal of Hindu Science and Religious Studies, 1(1), 1-13.

Wattimena, Reza A.A., 2012. Sesudah Humanisme Sebuah Resensi Buku. http://rumahfilsafat.com. Diakses pada 28-02-2015.
Ziaulhaq, 2011. "Membangun Teologi Temu Mesra Agama" dalam Makalah disampaikan dalam Musyawarah Komisariat Kader HIMMAH SeKawasan IAIN SU dengan tema "Diseminasi Kerukunan Umat Beragama di Kalangan Mahasiwa" di Kantor PW Al-Washliyah Medan.

Ziaulhaq, 2010. "Perspektif Puasa tentang Kerukunan Beragama”. dalam Harian Waspada.

Ziaulhaq, 2009. Islam Humanis: Мепијu Interpretasi Berwawasan Kemanusiaan. Bandung: Citapustaka Media. 